\title{
Semiotics of Islamic Law, Maṣlaha, and Islamic Economic Thought
}

\author{
Sami Al-Daghistani ${ }^{1,2,3,4}$
}

Published online: 5 February 2016

(C) The Author(s) 2016. This article is published with open access at Springerlink.com

\begin{abstract}
The paper explores the role and meaning of maṣlaha (social utility) and its possible appropriation in the field of Islamic legal and economic thought, as laid down by various medieval and contemporary Muslim scholars. Questions that are pertinent to the research are the following: how has mașlaha been incorporated in legal reasoning and what kind of meaning does it convey; what type of economic (and/or legal) reading does it presuppose; do ethics, law, and scriptural sources play equally important role as reference in developing the concept in economic terms, are some of the questions that this paper will try to provide answer to. Further, as there is a tendency to believe that Islamic economic thought cannot be equated only with legal and juridical underpinnings, it is pertinent to pose a question if economic ideas have flourished independently from its legal framework. Mașlaḥa in its capacity has always remained part and parcel of Islamic legal theory, and has been rarely addressed within the frame of economic thought; therefore a new reading is required to deal with the position of economic teachings within Islamic tradition. The paper consists of three sections, whereby the contributions made by Muslim medieval scholars on Islamic economics will be presented. The first chapter provides a historical overview of Islamic law and the concept of mașlaha in relation to the field of Islamic economics, including Abu Hamid al-Ghazali's monumental Ihya 'ulūm al dīn (Revival of Religious Sciences), which presents a milestone in converging Sufi ethical teachings of Islam in accordance with the legal methodology of Islamic law. The second part aims to discern and examine the economic jurisprudence and
\end{abstract}

Sami Al-Daghistani

Sami.aldaghistani@gmail.com

1 Leiden Islam Outreach Programme, Leiden University, Leiden, The Netherlands

2 WWU Münster, Münster, Germany

3 MESAAS, Columbia University, New York, NY, USA

4 Theodor-Heuss Str. 10, 48341 Altenberge, Germany 
economic theory in Islam as it is understood by some of the mainstream theoreticians of Islamic (economic) studies, advocating the view that Islamic economics is inextricably related to the gist of Islamic legal reasoning. In this section the ideas of Muhammad Baqr al-Sadr will be presented as he proposes a new reading of Islamic economics as a doctrine and not a science. The third part questions Islamic legal establishment and its normativity, the claim that legal norms have always been part of the Islamic economic reasoning. This claim rests upon the idea that Islamic legal patterns were also socially constructed, including some aspects of Islamic economic reasoning. Concluding remarks will draw upon the idea that despite the fact that Islamic legal and economic literature are based upon the religious scriptures of Islam, the Qur' an and Tradition, it is more appropriate to claim that they rest upon the ethical cosmology that surpasses purely theological concerns.

Keywords Maṣlaḥa or social utility · Islamic jurisprudence $\cdot$ Hermeneutics of Islamic law $\cdot$ Economic thought in Islamic tradition

\section{Introduction or How to Read Economic Teachings in Islamic Tradition}

The institution of mașlaha as social welfare pertains to the higher values of Islamic law and has in its capacity always remained part and parcel of Islamic legal theory. As such it has been rarely addressed within the frame of economic endeavors and activities, especially by the contemporary authors on Islamic economics. Since it also relates to the protection of wealth and social welfare, a new reading is required to deal with the position of economic thought within Islamic tradition. Exploring the role and meaning of mașlaha and its possible appropriation in the field of Islamic legal and economic thought will be conducted in light of various medieval and contemporary Muslim scholars. Since Islamic economic thought cannot be equated only with legal norms and juridical underpinnings, it is pertinent to pose a question if economic ideas have flourished independently from its legal framework. The notion of maslaha has been predominantly discussed within the parameters of Islamic law and legal discourse, yet it appears relevant for Islamic economic science for two reasons-due to the fact that Islamic economics has been studied as an integral part of the overarching concept of Islamic law; and since it includes and addresses also the institution of economic preservation, yet the modern deliberations of Islamic economics leave this institution pretty much out of sight.

Many modern Islamic scholars have always addressed the issues of Islamic economics within the given set of regulations of Islamic law, which indicates that they have rarely questioned the parameters of the Islamic jurisprudence and its very establishment. The classical scholars such as al-Ghazali addressed economic teachings within the framework of Sharī'a and its higher objectives. Yet contemporary scholars on Islamic economics have tackled the notion of epistemology and economic philosophy on the basis of the religion of Islam and legal normativity, leaving out the notion of economic justice and concepts related to it (e. 
g. mașlaha, istihsan,'adala, etc.). Therefore it is crucial to study the theoretical framework of the contemporary scholars on Islamic economics. In this paper I analyze how has mașlaha been incorporated into legal reasoning and what kind of meaning does it convey in relation to economic endeavor in Islamic tradition. This question will be addressed through various sub-questions consisting of several chapters: how did mașlaha as a concept develop and what type of economic and legal reading does it presuppose; what are the sources of economic teachings in Islamic tradition; is Islamic economic theory in the contemporary period regarded as a subsystem of Islamic legal normativity, and why is there a need for critical study of Islamic legal and economic thought. The paper consists of three sections. The first chapter provides a historical overview of Islamic law and the concept of mașlaha in relation to the field of Islamic economics, including Abu Hamid alGhazali's monumental Ihya 'ulūm al dìn (Revival of Religious Sciences), which presents a milestone in converging Sufi ethical teachings of Islam in accordance with the ethical considerations of Sharì'a. In this section the following topics will be addressed: the history and role of Islamic law, the meaning of the "common good" in Islam, and Muslim scholars' views on mașlaha. The second section aims to discern and examine contemporary economic jurisprudence and philosophy in Islam as it is understood by some of the mainstream theoreticians and scholars, advocating the view that Islamic economics is inextricably related to the gist of Islamic legal reasoning. Among others, the ideas of Muhammad Baqr al-Sadr will be presented as he proposes a new reading of Islamic economics as a doctrine and not a science, beside scholars like Muhammad Khan, Rauf Azhar, Siddiqi, Choudhury, Chapra, Muhammad A. Haneef and Abbas Mirakhor who have dealt with the subject of Islamic economics and its subject [10,2013]. The third section questions the Islamic legal establishment and its normativity, the view that Islamic economic reasoning has always been part of Islamic legal norms. This claim rests upon the idea that Islamic legal patterns were also socially constructed and that differentiating Shari $a$ as a spiritual and ethical concept from fiqh as Islamic law is indispensable in order to define the subject matter of Islamic economics. Concluding remarks will draw upon the idea that Islamic legal and economic literature is indeed based upon the religious scriptures of Islam, the Qur'an and Tradition, however, as it will be shown, it is more appropriate to claim that they rest upon the ethical cosmology that surpasses purely legal concerns and norms.

Semiotics inquires upon the meaning and the production (or rather representation) of signs. It is regarded as a scientific method in the fields of linguistics, literary theory and general humanities and stems from Saussure's principles, surpassing structuralism. For Saussure, semiotics (semiology) as a study of signs presents a basis for not only linguistic inquiries but also social phenomena, and therefore linguistics become a part of social sciences. This is the reason why the science of signs is only a component within the general science of signs, that is, semiology [38, p.123-124]. The definition of semiotics presupposes its societal nature, and it deals with signs or rather how signs produce meaning. The concept thus generates socialness, and it is a multidisciplinary field of study dealing with issues related to communicating in various sign systems [38, p. 128.] The object of semiotics can be anything that can be studied as a sign system, including rituals, art, law, and 
economy. Every structural praxis can be regarded in its relation to the nature of language, and moreover, hermeneutics. Umberto Eco contends that semiotics has "to explain why something looks intuitively, in order to discover under the felicity of the so-called intuition a complex cognitive process" [39, 2001] and has thus linked the field of semiotics from a hermeneutical approach. Semiotics can be regarded as a systematic study of all factors that are part of the production of sign; its object can be anything that can be perceived as a sign system. Since social praxis also includes the fields of law, economics, and the cultural processes these fields generate, they are seen as sign systems. According to Toshihiko Izutsu, moral code is one component of an overall ideology, embedded in its linguistic system, and therefore represents a certain worldview (Weltanschauung), which is interpreted accordingly [31, p. 176]. Examining the field of Islamic economic thought would refer to the production of sign in (re)interpreting the development of Islamic legal normativity and the notion of mașlaha as social utility. By doing so one would readdress the foundation of Islamic legal discourse that has incorporated economic thought in Islamic tradition as per se legally-binding and therefore normative. The notion of mașlaha and its relation to the field of Islamic economics can be interpreted through what is in Islamic tradition known tafsì [ Tafsì- - from the root fassara, "to explain", "elucidate", or afsara, "to break". The verbal noun occurs in the Qur'an in 25:33 and came to be technically interpreted for Qur'anic exegesis, Esack [18] and $t a$ 'wīl [Ta'wīl from the root '-w-1, "to interpret" or "to elaborate" refers to esoteric (bātin) reading of the exegesis, invoking hidden and allegorical readings. Esack [18].

\section{Historical Perspective on Islamic Jurisprudence and Maṣlaha}

Semiotics is being interested also in the representation of law, hence this chapter will look into the historical development of Islamic law and how the concept of mașlaha developed. Critical examination of the development of Islamic economics inevitably encompasses the field of Islamic legal discourse and its normativity. The latter inextricably relates to maqūșid al-Sharì'a or objectives of Islamic law since it advocates, among other elements, economic preservation and can be used as a vehicle for legal change.

Islamic law or Sharī'a has been perceived as the "immutable Divine law," whereby the rules (ahkām) derived from the Qur'an and the deeds of the Prophet of Islam (Sunna) can be seen as an interpretation of reality. For many classical as well as contemporary scholars Sharī' $a$ has been the core of the understanding of Islamic legal principles [2], 1413AH; [27, 28], 1999; [27, 28], 2006]. Whilst the tawhìd epistemology is rooted in the Qur'an, the science of Sharī'a is called fiqh, and fuqaha' are considered specialists in legal matters. The four basic Sunni Islamic schools of law-Hanafī, Mālikī, Shāfi'̄̄ and Hanbalī-agree that the four fundamental sources of Shar'̄'a are: the Qur'ān, Sunna, ijmā' or consensus and qijās or analogy. Classical Muslim scholars perceived Islamic economic thought as part of the Islamic theology of kalām from which they derived juridical rules [1, Vol. 2, p. 60]. They invoked theology when discussing legal and economic precepts 
to tackle various Sharī'a-stipulated questions. Mașlaḥa as part of Islamic law has always been part of fiqh literature, yet due to its aims to preserve human life, it is vital when addressing also economic problems; it appears crucial for preserving the objectives of Shari'a, protecting human existence and wealth.

Maqāssid al-Sharì'a, the higher aims or objectives of the Divine law, provide wisdom for the legal rulings and social welfare, and can be seen as divine intents and moral concepts dealing with justice, social welfare, human dignity and preservation [34, p. 1]. The objectives of the Sharī' $a$ were presented by different Islamic scholars; traditionally, maqāsid did not include the notion of justice. This concept was extracted from fiqh literature and was not deduced from studying the original sources [34, p. 4]. Contemporary scholarship on maqāșid introduced more detailed, universal precepts in comparison to fiqh literature [27, 28, 1999)]. For some scholars, maqāṣid today represents legal change and reform [19, 2010]. The objectives of Islamic law evolved after the Companion era, yet their meaning as we know them today were introduced much later, during the 11-15th centuries AD. With the emergence of the philosophy of Islamic law, al-Jawayni in the 11th century utilized maqāssid for his theory on necessities and needs. He coined it by proposing five levels of maqāșid: necessities (darūrāt), public needs (al-hājah al-'amah), moral behaviour (al-makrumāt), recommendations (al-mandūbāt), and specifics [34, p. 17]. Al-Ghazali elaborated them further in order to provide provision for the wellbeing of humankind, by safeguarding the categories of faith (din), human self (nafs), intellect ('aql), offspring (nasl), and wealth (māl) [2, Vol. I, p. 286-287]. Traditionally, the scope of maqāșid is the whole of Islamic law. Al-Shātibi (d. 1388 $\mathrm{AD}$ was a famous Islamic legal specialist who wrote on the objectives of Islamic law) furthered al-Jawayni's and al-Ghazali's theory, and for him mașlaha should be primarily concerned with the benefit of the people. The concept encompasses the preservation of human life or soul, one's livelihood, intellectual qualities, religious expression, and procreation or descendants.

There are three stages of mașlaha: (1) darūri or essential, (2) haji or complementary, and (3) taḥsini or amelioratory [20,7]. The basic level of mașlaḥa incorporates five elements, aiming to preserve the dignity of human life or to prevent harm from human beings. The first level takes precedence over the second, and the second over the third. According to Fahim Khan, many economic agents can be derived from the objectives of Islamic law as it was explored by al-Shātibi and al-Ghazali. In this regard mașlaha would determine whether an economic activity (like consumption or production of a good) should be pursued or not. If any activity does not have a beneficial implication corresponding to Shātibi's framework of objectives of Sharì'a then that activity should not be pursued (in production or consumption of exchange). Since maqāsid al-Sharì'a appears to be crucial in the development of Islamic law and Islamic economic teachings, this indicates that an economic agent will try to seek mașlaha instead of utility in a conventional sense. Utility relates to the subjective conceptualization deriving from individual endeavours, whereas mașlaḥa "is amenable to objective verification" and pertains also to society as a whole. Individual-based economic endeavours are regarded as undesirable for they do not correspond to the ethical concept of mașlaha [1, Vol. 3 p. 234; Vol. 4, p. 101]. Since mașlaha leads to fulfilling needs it advocates the idea 
of regulating wants. Likewise, it provides basic needs for social welfare, something that conventional economics precludes.

Historically, the Muslim community was affiliated with trade, familiar with market functioning as well as the difficulties related to it. The notion of administrative fixation of price was known already in the time of the Prophet Muhammad, whose discouragement against it stemmed from his belief that it endorsed price fixation by market forces - that is, according to supply and demand [34, p. 25]. Medieval Muslim scholarship developed advanced ideas on economic philosophy and “Arab Scholastics were about as 'European' as any scholarship at the time," [21, p. 49] since for centuries almost all intellectual developments and exchange of knowledge took place in the Mediterranean.

Throughout the history of Islam, the position of Islamic economics has been regarded as an integral part of Sharī' $a$ as the ethical path to righteous behaviour, and not necessarily as the Islamic legal codification. The evolution of Islamic economic thought can be traced back to the earliest period of Islam (7th century AD), as economic issues had been considered by Muhammad and the Rashidūn or four rightly guided caliphs. However the context in which they were raised and addressed was different. In the first centuries of Islam, various economic issues, e.g. the prohibition of usury and the encouragement of economic activities for human welfare, were discussed in light of the holy Qur'an and the Divine law, [4, 1979].

Islam has never stifled human beings from engaging in economic activities [36, p. 148]; on the contrary, it has encouraged the purchases of what is regarded as "licit" commodities. An active role in economic activities in society is encouraged, however, the hoarding of wealth and food supplies is illicit for many Islamic medieval scholars [1, p. 72], as a merchant should always sell his commodities at a fair value [Ibn Taymiyya (1982) pp. 32-33 in 14, p. 194], according to the regulations set on markets. Economic thought is an integral part of human society and is therefore indispensable to other dimensions of human life. In the Islamic tradition, economic science shapes the very nature of the human viewpoint of worldly endeavours [36, p. 12]. At least four different dimensions of economic analysis can be identified [36, p. 148]: (1) Studies that relate to economic issues within the discipline of tafsīr (exegesis) as a hermeneutics of the Qur'an, e.g. prohibition of usury, (2) Economic matters within the discipline of fiqh (Islamic jurisprudence), e.g. the contemporary aspects of Islamic economics, (3) Elaboration upon economic questions from the perspective of Islamic ethics by Islamic economists, Sufis, Islamic philosophers and others, and (4) Numerous works on economic science written by Islamic scholars as a response to the growing need of the time.

According to the above-mentioned differentiation, in the contemporary era Islamic economic doctrine is approached from the second and fourth positions, since it is viewed as a by-product of Islamic legal principles and prescriptions, derived from the Qur'ān and the Tradition. As such Islamic economics is predominantly interpreted by religious scholars through the legislative regulations, aiming to accommodate ethical teachings of Islam into the field of economic activities [10, xixiii]. 


\section{Contemporary Islamic Economic Thought as the Subsystem of Islamic Legal Discourse}

Contemporary Islamic economics is regarded as a new discipline [12] motivated also by the intellectual development in secular schools of thought from the 19th century, including the so-called "Islamization of knowledge" process [e.g. [8, 25, 7, $6,24]$. It emerged as a distinct field of study in the second half of the twentieth century. Efforts to develop the science of Islamic economics stem from the Revivalist movement of the nineteenth and twentieth centuries [10, xi]. Akram Muhammad Khan distinguishes two movements that advocated the development of Islamic economics as a science. The first "modernist movement" resorted to ijtihad in reinterpreting the Qur'an and Sunna in light of the pressing socio-economics needs of the time, while discerning fiqh rules from Shari' $a$ as an overall concept. In the modernist camp belonged Jamal al-Din al-Afghani, Muhammad Abdu, Rashid Rida, Muhammad Iqbal, Muhammad Asad, Fazlur Rahman, Rauf Azhar, and others. If spiritual and material do not differ, then also economic and financial activities are meant to be read within religious context. The second group comprises of scholars such as Hasan al-Banna, Syed Qutub, Abu al-'Ala Mawdudi, Isma'il al-Faruqi, Nejatullah Siddiqi, Umer Chapra, Anas Zarqa, Choudhury and Muhammad Baqir al-Sadr, advocating a more literal reading of the sources of Islam and implementing their ideas with limited excursion of ijtihad or independent legal reasoning into the socio-economic sphere. ${ }^{1}$ This group has advanced the idea that Islam has its own distinct economic system, whose rules and basic premises can be deduced from the scriptural sources. From these discussions, Islamic economics emerged as a distinct science, rooted in the Islamization of knowledge process; following suit was its subsidiary branch of Islamic finance and banking, attracting many Muslim scholars and laymen [10, xiii].

The aforementioned Muslim scholars of the nineteenth and twentieth centuries did not use the terms "Islamic economics" or "Islamic finances," but discussed the socio-political realities in relation to the revival of theological teachings in Islam. It was only with religious scholars like Abu al-'Ala Mawdudi, Muhammad Baqir alSadr and later with Naqvi, Umer Chapra and Nejatullah Siddiqi that the term "Islamic economics" emerges as a distinct subject, wherein the principles of the Islamic worldview, inheritance, finances, charity tax, and interest are considered. Contemporary Muslim scholars aimed to discern and define the Islamic worldview [15] and its possible ramifications for economic behaviour, developing social science based on a theological foundation, and instead of incorporating and resorting to economic (theological, Sufi, or philosophical) teachings of the classical and medieval Muslim scholars, the contemporary authors predominantly relied on their own understanding of the theological and legal stipulations of the so-called Qur'anic epistemology of unity, coupling the field of economic teachings with modern financial issues. Yet their aim and methodology were not clear, since

\footnotetext{
1 Since it is impossible to discuss in detail all of the above-mentioned modernists, the most relevant authors in relation to their ideas, either on Islamic economics or Islamization process, will be presented and analyzed.
} 
modern scholars defined Islamic economics as a discipline driven by fiqh stipulations, social justice and human-endeavours within the social sciences. They typically described "a model economy that did not exist in the real world" [10, p. 4] and found themselves engaging primarily with the discipline and methodology of Islamic law. Merging Islamic economics, which was in its essence a poorly defined discipline with finances and Islamic law, did not yield theoretical analysis that would include also classical Muslim scholars and their ideas of economic teachings.

Islamic economics as a study was developed in Sayyid Abil-Ala Mawdudi's book The Economic Problem of Man and its Islamic Solution [29, p. 155-156]. However in this work, the concept of economic justice, one of the key terms of contemporary scholarship, is largely absent, and if present at all in its deliberations, it is theorized predominantly within a legal framework and using juristic parameters. Since modern Islamic economics as a field tends to be equated with the process of Islamizing the study of economics [29, p. 156], the research inevitably addresses also the Islamization of knowledge process coined by Faruqi, encompassing various fields of study and branches of knowledge under the banner of Islam and Islamic ethics. The role of economic justice is crucial in readdressing the historical value of what we by common denominator call "Islamic economic thought."

Scholars like Naqvi and Siddiqi base their theory of Islamic economics predominantly on Islamic ethical and legal conceptions respectively, following the norm of "commanding the good and forbidding the evil," which includes the forbiddance of hoarding, and other economic provisions. The notion of mașlaha as (socio)economic justice in Islamic economy is left out of this discussion. For Choudhury the Islamic worldview rests upon the premise of the Oneness of God or tawhìd [16, p. 8], including the socio-economical field; Islamic political economy can be regarded as "the study of interactive relationship between polity (shüra) and the ecological order (market subsystem)" [17, p. 369]. These links are established to levitate the human development of social interactions and economic stipulations within the institution of Sharì'a.Muhammad Akram Khan proposes the following definition of Islamic economics, linking the notions of common and individual undertakings: "[It] aims at the study of human falăh (derives from Arabic verb aflaha-yuflihu - to thrive, achieve happiness, success etc.) achieved by organizing the resources of the earth on the basis of cooperation and participation" [9, p. 33]. The Qur'an emphasizes that falāh (individual and common success or good) has to be achieved in worldly life, although the ultimate goal is the faläh in the hereafter. The notion of falāh has to be categorized in spiritual, economic, cultural and political domains, and can be differentiated on the basis of survival (physical health, economic base, social brotherhood, political participation etc.) and freedom (selfreliance, respect, civil liberties etc.). These two categories exist on the personal (micro) as well as state (macro) levels [9, p. 59]. As Khan asserts, due to human self-interest, material progress, and the inherent tendency to maximize material welfare [9, p. 59], the Islamic tradition deals with fairness and equity also in the field of economics. Material welfare is not considered the supreme force that empowers Muslim societies, since modesty and piety are features of a rightlyguided Muslim, including the Prophet of Islam. The institution of zakāt (Islamic wealth tax levied on savings and assets) has also been reserved for the weak to 
balance wealth and increase social welfare among population [37, Qur'an 4:28, 100:8]. Zakāt not only has religious-moral but a socioeconomic character as well, yet it has not been institutionalized which would increase mașlaha or prevent economic harm. Prohibition of ribā [interest on capital loan, 9, p. 25] or excessive interest, which was common among pre-Islamic Arabs, is also based on the Qur'ān, which aims to prevent the wealthy's exploitation of the poor and needy. Islamic tradition has distinguished commercial activity from profit and the prohibition of riba $\bar{a}$. The main reason rib $\bar{a}$ was put into force was to avert the accumulation of wealth in order to diminish the economic differences between different layers of society and social fabric [37, Qur'an 2:275]. Khan argues that Islam generally encourages market economy through the imposition of a certain degree of ethicallydriven regulations and government intervention that mean to disable the exploitation of economic power and the accumulation of wealth: "Islam envisages a world in which everyone with authority is accountable for his actions" [9, p. 4], in order to establish an economic order based upon the ethical regulations of Shari'a. Scholars like Sohrab Behdad remain skeptical when claiming that fair exchange in Islam has never been socially or otherwise prescribed, despite the fact that the Qur'an explicitly condemns usury: "Those who consume interest cannot stand [on the Day of Resurrection] except as one stands who is being beaten by Satan into insanity" [37, Qur'an, 11:275]. The prohibition of usury, imposing monopoly over business, hoarding of money, and speculation are regarded unlawful according to Islamic financial arrangements-yet Behdad maintains that there is no upper limit in Islamic jurisprudence that would limit the acquisition of capital. This means that one could theoretically gain as much wealth as possible, hence "Islamic Sharī'a would not prevent rapid accumulation and high concentration of capital in a market economy, even in an underdeveloped one." [14, p. 201] However, even if there is no jurisprudential limitation on the acquisition of wealth, if ethical stipulations are reconsidered this might put forward the idea of social balance and just economic purchases after which it is rather unlikely (yet not theoretically impossible) that this would became a prerogative in Islamic economic thought.

Muhammad Baqir al-Sadr' Iqtiṣāduna (Our Economics) also discussed social balance and ethical consideration in Islamic economics. It is an important intervention in contemporary Islamic legal thought and economics, differentiating between the system and science of economics [3, Vol. 1, p. 89-94, Vol. 2, p. 5-15]. Khan positions al-Sadr in the "Islamization group," arguing that he seeks to justify a new economic paradigm in opposition to capitalism and socialism. The capitalist economic system, which for al-Sadr generates economic inequalities, is based upon three specific points: freedom of ownership, freedom of exploitation, and freedom of consumption [3, Vol. 1, p. 6]. Al-Sadr argues that despite the apparent difference between capitalist and Marxist economy in addressing the issue of private rights and ownership, both systems similarly endorse an individualistic-oriented perception of nature. Since the capitalist perception of free society rests upon the materialization of personal interests, it is the individual upon which the society functions, excluding from its epistemological frame the ethical and spiritual values of addressing economic behaviour within the larger picture of human social and individual engagement. 
Al-Sadr asserts that Islamic economics differs substantially from capitalist and socialist systems in three elements: first, in respect of its nature and definition of ownership since in Islam the notion of double ownership is possible [3, Vol. 1, p. 49]. Private ownership is not a general rule in Islamic but in capitalist economy, which does not recognize public ownership as being beneficial for the public. On the contrary, in socialist society only public ownership exists, whereas common ownership is a general principle in Islam [3, Vol. 1, p. 50]. Islamic economic doctrine disagrees with private or public ownership as a fundamental principle, but sets up different forms of ownership simultaneously-be they private, public, and/or state. Thus, according to al-Sadr, it is incorrect to call Islamic society a capitalist one even if it allows a number of seemingly capitalistic appropriations within the means of production, as this is a manifestation of an era and not an ethical prerogative. The Legal Precepts $(a h k \bar{a} m)$ for al-Sadr extend to the distribution of wealth, including private, state, public ownership, umma-ownership, people's ownership, and common ownership (state and public) [3, Vol. 1, p. 64-72]. Even though al-Sadr had exercised ijtihād in the domain of contemporary Islamic economic thought, he recognized that it is not error-free. In addition, Islamic economic doctrine does not recognize exclusively private ownership. The second element is the principle of economic freedom, which is obstructed due to the ethical and spiritual components and objective restrictions related to the social behaviour (sha'r). The third element is the principle of social justice (related to mașlaḥa), which is embodied in an Islamic economic fabric in the system of distribution of wealth. Social justice within this framework pertains to two general principles: first, general reciprocal responsibility and second, social balance [3, p. 51-60]. The proposition is to study Islamic economics as part of a worldview. The interconnectedness of the Islamic economy with the concept of Islamic belief relates to the explanation of ownership rights and social responsibilities, and it thus cannot be approach on purely material grounds.

As far as the nature of Islamic economics is concerned al-Sadr claims that it is not a science, yet it can constitute a scientific inquiry through comprehensive religious study. Economic doctrine differs from economic science; the first presupposes an expression of the way of life society prefers to follow, the latter gives explanation to the economic life. According to this differentiation, Islamic economics is regarded as a doctrine, for it is the way Muslims pursue their economic gains. Doctrine is concerned with the distribution of wealth, whereas science with the laws of production [3, Vol. 2, p. 5]. If this differentiation is to be attained, then analysis of economic theories would be regarded as the science of economics, whereas economic behaviour of man as doctrinal.

Al-Sadr's theory on Islamic economics as doctrine is unique, however it should be understood and located using a historical lens, since Islamic banking and the lucrative financial systems of the 21 st century (along with the rigid jurisprudential literature of pre-modern Islamic economics) do not analyze the nature and the subject of Islamic economics in a comprehensive manner. In accordance with alSadr's motivation, since Islamic economics has a specific ethical-social narrative that relates to the means of production, consumption, commercial exchange and distribution, it ought to be seen as a system [33, p. 41], managing a worldview 
"where the ontological and epistemological sources namely the Qur'an and hadith determine the framework of the economic value system, the operational dimension of the economy and also the economic and financial behavioural norms of the individual Muslims" [11, p. 10]. If the gist of Islamic economic doctrine rests upon the notion of (economic or social) justice, it presents an economic axiom embedded in the doctrine. For this reason al-Sadr defines Islamic economics in light of justice as "the way Islam prefers to follow in the pursuit of its economic life and in the solution of its practical economic problems in line with its concept of justice" [3, Vol. 2, p. 6]. According to Rodney Wilson, "his approach was holistic, and it can be categorized as 'juristic-economic' with the moral valuation of economic actions playing the central role." [35, p. 47]. On the other hand al-Sadr deduces economic principles from Islamic law [3, Vol. 1, p. 57-58], prioritizing also individual responsibility as one of the many factors for a moral economic endeavour.

Al-Sadr's theory of economics has been studied by Ali Nayed who has defined two types of Qur'anic interpretations: "divisive" and "unitary." The first method considers the interpretation of the Qur'an verse by verse [32, p. 443]. Al-Sadr believed that the "unitary" or "topical" (mawd'i) interpretation ought to be utilized, as this type is not verse-based but studies the Qur'an based on a topic-be it religious, social, or otherwise. The Qur'an can easily be tailored according to how one reads it, and even more so, if one reads it according to only one theme or topic. Al-Sadr, who was a Shi'a theologian, reads the Qur'an relying on the tradition ascribed to the fourth rightly guided caliph and Prophet Muhammad's son-in-law, 'Alī ibn Abī Tâalib [32, p. 445]. The method'Alī resorts to is called istintaq, which means "to make speak," thus by invoking this unitary interpretation in light of human experience of a certain theme, the interpreter investigates the chosen topic [32, p. 445]. For al-Sadr the line of distinction in what constitutes science and doctrine is the ideology of social justice: "The economic doctrine consists of every basic rule of economic life connected with the ideology of social Justice. And the science (of economics) consists of every theory, which explains the reality of economic life apart from a prefixed ideology or an ideal of Justice" [3], Vol. 2, p. 9]. This asserts that the economic preservation and expropriation of the social right is intrinsically embedded in the doctrine of Islamic economic writings.

According to Mirakhor, Islamic economy rests predominantly upon the rules of the law and the teachings of ethics, providing social justice within the frame of mașlaha. To set new parameters of Islamic economics, whereby the subject matter and epistemology of Islamic economic doctrine would be analysed, a hermeneutical model is needed as "a systematic, rigorous and analytic economic interpretation of sources of Islam" [30, p. 18]. In addition to the main four legal sources named earlier, this should also include the economic history of Islam and the reexamination of the corpus of Muslim legal specialists as well as the impact legal theory had on Islamic economic thought. In addition to the Islamic law and legal rules, the ethical consideration of the Qur'an and its interpretation of human being as a morally (and thus socially) responsible being, along with the notions of mașlaha, imān, sadaqā, taqwā and others, have overall moral implications on economic behavior. The hermeneutical reading of the first centuries of Islam would also reveal a great deal of understanding on social and political ramifications of 
economic behaviour, such as the "supervision of the market, mechanisms of production and the process of equilibrium in economy." [30, p. 21] Another important source of hermeneutics of Islamic economics can be provided through the definition of (social) justice ( $a d l$, mizān, qast, haq) and beneficence ( $a l$ - 'adl wa al$i \grave{h s} \bar{a} n$ ) within the realm of economic conduct, a topic which is linked to Islamic legal discourse.

\section{Questioning the Legal Establishment of Islamic Economic Teachings}

As indicated above, contemporary Islamic economics is predominantly concerned with licit and illicit conduct according to legal normativity, covering topics of economic transactions, operation of Islamic banking system and other predominantly juridical-technical matters. As such it condones primarily legal-religious considerations and, to a large extent, it repudiates philosophical and mystical contributions made by Muslim scholars. In the following pages, a view which opposes the mainstream contemporary claim of Islamic law as a legal manifestation of Sharī' $a$ as the Divine law will be presented, since economic thought in Islamic tradition to a large extent pertains to ethical and theological premises integrating the notion of economic justice.

Economic institutions were in Islamic tradition also a product of legal reasoning. Every legal system is located within a spectrum of rigidity and flexibility. Islamic law, despite its characteristic as being a Divine law, stimulated various economic and socio-political developments, and as such "the autonomy of the law, in short, does not lie in the system itself, but rather in the social order in which it is embedded" [26, p. 257]. Islamic law was in the pre-modern period not an elitist enterprise disconnected with the general public; however, access to rule-making and rule-giving was procured for those who mastered the scriptural sources and customary laws. In addition, political and interest-based endeavours of bending certain rules within the law were practiced by Muslim jurists, yet despite that the orthodoxy of the law was established in the formative period; during such times, it was unlikely that Islamic law presented a fixed, defined, and unchangeable legal structure, even when addressing socioeconomic purposes.

This view is extended to the Islamic economic tradition, which does not stem only from fiqh literature and religious questions. Historically speaking, economic activities have surpassed legal precepts. While Islamic economic activities might be perceived as "Islamic," they are not necessarily legally stipulated. Hence Islamic economic doctrine does not necessarily fall under the corpus of Islamic legal system, despite its religious character.

One of the earliest Islamic legal scholars and eponym Abu Haniffah (d. 767 A.D.) in his work The Great Understanding-al-Fiqh al-Akbar stated that "understanding (fiqh) in religious matters $(d \bar{l} n)$ is better than understanding ( $f i q h)$ of scriptural sources of law ('Urn) and legal statutes (al-hudd)" [35, p. 188]. Fiqh can be understood and read as a product of religion, and "fiqh-law is therefore not legislated but understood, not produced but discovered and formulated" [35, p. 188]. A closer look at fiqh science presupposes that one cannot study Islamic law without 
engaging Islamic theology, indicating that Islamic law has to be studied through its ethical and epistemological implications. This indicates that Shar or Sharì'a is the moral imperative which was set by the Qur'an as a revelation, whereas fiqh was provided by the Prophet Muhammad upon which Muslims after his death are invited to act upon. Hence the correlation between the mundane and the divine realm is managed by understanding (fiqh) rather than by actual statutes ( hudüd). This further presupposes that economic behaviour falls into the realm of ethical considerations and not necessarily under the category of legal prescriptions.

According to Wael Hallaq [23, 2009], Islamic law was not parted from the conception of the Qur'anic morality in the pre-modern era, therefore the dichotomy between the two epistemic systems did not exist. In modern times one tends to associate the term morality with classical Islamic (Qur'anic) exegesis, whereas law (practice) and theory (ethics) are placed on another level, as if belonging only to one narrative. The Qur' an provided Muslim society with moral, natural laws and a new cosmology enhancing a moral system that transcended purely theological categories, as it was "constructed out of the moral fiber." This view presupposes that human deeds are dependent on a particular worldview. And because (socio) economic behaviour has primarily an ethical consequence, the contemporary scholars believe that Islamic economic theories should be perceived as binding to the subjects of the Law. Yet Islamic economics do not necessarily carry legally binding codes, but they are rather linked to ethical principles, related to philosophical and theological ideas. If Islamic economics is distinct from its fiqh rules, then discrepancy between Sharī' $a$ as the immutable Divine law and Islamic law as a manifestation or attempt to apply the Divine law within the human maintained judicial system is apparent on an epistemological level. Islamic law has always been perceived as religious law with the Divine character [On Islam as the culture of ambiguity, including the realm of Islamic law, see 13, 2011]; however, this Divine aspect was made absolute, as if the secular aspect of Islamic law is nonexistent. This view can be easily extended also to the domain of Islamic economics. Namely, Sharì'a as God's law relates to fiqh and legal stipulations to ahkam. Classical works on Islamic law reveal a high level of probability theories (Wahrscheinlichkeittheorie) of the divine law, seeking to frame it within the parameters of Shari'a as the immutable law. This attempt was not always successfully applied, for Islamic law dealt predominantly with socioeconomic, political, and administrative issues and less so with the purely theological [13, p. 158]. ${ }^{2}$ Bauer claims that Sharī' $a$ is "a collection of God's assessments of human conduct" (hukm). This crucial element has often been misunderstood as legal injunction or prescription. Primarily, hukm (rule) is God's speech (kalām) which deals with human conduct. According to religious scholars, God's speech does not necessarily rest upon man's appropriation of it [13, p. 158]. Explaining how jurists and scholars came to deduct these ahkam from the religious scripts has been the task of usül al-fiqh, the roots of the law or rather legal methodology, which is in its

\footnotetext{
2 Out of 187 legal writings collected by Hadjdji Khalifa in the 17th century, no books contained the term Sharī' $a$ in their titles. See Hadjdjī Khalīfa, Kashf az-ẓunūn, Bd. 2, $261 \mathrm{f}$.
} 
essence an endeavour of learned men to understand and interpret the sources of the law [See [22], 1994].

One of the main differences between classical and contemporary scholars on Islamic economics is that the former based their arguments on a theological base, whereas the latter on legal. Many contemporary scholars believe that Islamic economics falls under the category of Islamic law, since Islamic economics builds upon Islamic economic knowledge, established by the fuqaha and Muslim scholars. Yet the Sharì'a ethical patterns differ from the deducted norms and values of the Islamic legal codes that constitute the sum of Islamic economic science. Undeniably Sharì'a guidelines form the axioms of Islamic economics, covering the issues of food, clothing, money utilization, purchase of commodities etc., and stem from Qur'anic ethical teachings [37, Qur'an 25:67]. ${ }^{3}$ However, an Islamic economic system does not rest only upon Islamic legal precepts, since an economic problem is distinct and cannot be solved only by fiqh rules [5, 2002]. In other words, despite the presence of legal norms when exercising economic activities in Islam, to claim legal normativity of Islamic economics, i.e. that it intrinsically maintains a legal character, might be misleading. Sharī' $a$ as the Divine law does not address only the institutions of zakat and ribā, but various other ethical concepts, and therefore it seems appropriate to dispense the term "legal normativity" of Islamic economics and to introduce the term "ethical cosmology" of Islamic economics, due to its distinct characteristic. In the light of this distinction, Islamic economics ought to be studied through the theoretical corpus of Islamic intellectual history and Islamic ethics.

\section{Conclusion: Islamic Economic Thought-Between Legal Normativity and Economic Philosophy}

The article examined the underlying connection and interpolations between Islamic law, primarily as a theoretical concept and mașlaha as a tool for legal change within the realm of Islamic economics. Views on that topic were presented by certain medieval Muslim scholars and contemporary theoreticians. The first section focused on the historical contributions to the field of Islamic law made by the medieval Muslim scholars. The second section of the article inquired upon the contemporary claims made by religious and legal scholars that Islamic economics constitute one part of the legal constellation of Islam. The third section opposed this view, introducing the idea that Shar' 'a as Divine Law has never been put completely into practice in the form in which it was revealed, due to the human understanding and interpretation of it, which entails re-examining the sources of Islamic law and economics.

The sources of Islamic economics are the religious scripts of Muslims-the Qur'an and Sunna-from which Islamic legal norms and decrees were deduced, including activities related to commercial purchases and economic behaviour.

\footnotetext{
3 "True believer would not be extravagant nor miserly (Qur'an 2:275). On prohibition of usury: "but Allah has permitted trade and forbidden usury (100:8).
} 
Classical Muslim scholars have addressed mașlaḥa as one of the main concepts to discuss legal matters. Even though the provision of socio-economic justice appears to be one of the key premises advocated by contemporary authors, save Umer Chapra and Siddiqi, the contemporary authors do not address economic postulates in Islamic tradition through the concept of mașlaha. Sharì'a was seldom regarded as legal normativity per se, in the sense of being a direct manifestation of the Divine Law, but rather as an interpretation by the learned men. This view asserts that Islamic economics ought not to be equated as a subsystem of Islamic law but should be instead looked upon in light of the ethical and spiritual teachings of the Qur'an and Tradition, especially by invoking the concept of the higher objectives of Islamic law. This approach breaks apart from the conventional understanding of Islamic economics as being primarily law-binding and is thus regarded as an important distinction between classical and contemporary economic philosophy which needs yet to be bridged in order to attain full understanding of economic teachings in Islamic tradition.

Open Access This article is distributed under the terms of the Creative Commons Attribution 4.0 International License (http://creativecommons.org/licenses/by/4.0/), which permits unrestricted use, distribution, and reproduction in any medium, provided you give appropriate credit to the original author(s) and the source, provide a link to the Creative Commons license, and indicate if changes were made.

\section{Referenecs}

1. Al-Ghazali, Abu Hamid. Ihya' Ulūm al-Dīn (The Revival of Religious Sciences). Beirut: Darul Nadwah, n.d., 4 Vols.

2. Al-Ghazali, Abu Hamid. 1413AH. Al-Muștasfā fi 'Ilm al-Usūl, ed. Mohammed Abdul-Salam Abdul Shafi, 1st ed. Beirut: Dar al-Kutub al-'Ilmiyyah.

3. Al-Sadr, Muhammad Baqir. 1987. Iqtișādunā (Our Economics) 3. Vols. Beirut: dar al-Ta'aarif.

4. Abu Yusuf. 1979. Kitab al-Kharaj, tran. Abid Ahmad Ali. Lahore: Islamic Book Center.

5. Abdel Rahman Yousri Ahmed. 2002. The Scientific Approach to Islamic Economics: Philosophy, Theoretical Construction and Applicability. Theoretical foundation of islamic economics. Ed. Habib Ahmed. Jeddah: Islamic Development Bank, Islamic Research and Training Institute, No. 3, 19-58.

6. Al-Attas, Syed Muhammad Naquib. 1992. Islam: The concept of religion and the foundation of ethics and morality. Kuala Lumpur: International Institute of Islamic Thought and Civilisation (ISTAC).

7. Al-Attas, Syed Muhammad Naquib. 1978. Islam and Secularism. Kuala Lumpur: Muslim Youth Movement of Malaysia (ABIM); reprint, Kuala Lumpur: International Institute of Islamic Thought and Civilisation (ISTAC), 1993.

8. Al-Mawdudi, Abul 'Ala. 1947. The economic problem of man and its Islamic solution. Lahore: Islamic Publications.

9. Akram, Khan Muhammad. 1999. an introduction to Islamic economics. New Delhi: Kitab Bhavan.

10. Akram Khan, Muhammad. 2013. What is wrong with islamic economics? Analysing the present state and future Agenda. UK, US: Edward Elgar Publishing.

11. Asutay, M. 2007. A political economy approach to Islamic economics: Systemic understanding for an alternative economic system. Kyoto bulletin of Islamic area studies. 1(2): 3-18.

12. Azhar, Rauf. 2010. Economics of an Islamic Economics. Leiden: Brill.

13. Bauer, Thomas. 2011. Die Kultur der Ambiguität. Eine andere Geschichte des Islams (The culture of ambiguity: A different history of Islam). Berlin: Verlag der Weltreligionen.

14. Behdad, Sohrab. 1989. Property rights in contemporary islamic economic thought. Review of Social Economy. 47(2): 185-211.

15. Chapra, Umer M. 2013. Islamic economics: What it is and how it developed. Paper written for EH. NET's Online Encyclopedia of Economic and Business History, accessed April 17th 2013, http://eh. net/encyclopedia/article/chapra.islamic. 
16. Choudhury, Masudul Alam. 2004. The Islamic world-system: A study in polity-market interaction. New York: Routlegde.

17. Choudhury, 1996. Towards islamic political economy at the end of the century. The American Journal of Islamic Social Sciences. 13(3): 388.

18. Esack, Farid. 1997. Qur'an, leberation and pluralism. Oxford: One World.

19. Felicitas, Opwis. 2010. Maslaha and the purpose of the law: Islamic discourse on legal change from the 4th/10th to the 8th/14th century. Leiden: Brill.

20. Ghazanfar, Mohammad, and Abdul Azim Islahi. 1997. Economic thought of Al-Ghazali. Jeddah: Scientific Publishing Centre King Abdulaziz Univesity.

21. Ghazanfar, S.M. 2003. Medieval Islamic thought: Filling the "great gap" in European economics. London: Routlegde.

22. Hallaq, Wael. 1994. From Fatawas to Furu: Growth and change in Islamic substantive law. Islamic Law and Society 1: 29-65.

23. Hallaq, Wael. 2009. Sharī'a: Theory, practice, transformations. Cambridge: Cambridge University Press.

24. Haneef, A.Muhammad. 2009. A critical survey of islamization of knowledge. Kuala Lumpur: IIUM.

25. Haneef, A.Mohamed, and Hafas Furqani. 2009. Contemporary Islamic economics: The missing dimension of genuine islamization. Thoughts on Economics. 19(4): 29-48.

26. Huff, Toby E., and Wolfgang Schuchter. 1999. Max weber and Islam. New Brunswick and London: Transaction Publishers.

27. Ibn Ashur. 2006. Treatise on Maqāsid al-Sharī'a, trans. Muhammad al-Tahir el Mesawi. London, Washington: International Institute of Islamic Thought (IIIT).

28. Ibn Ashur. 1999. Maqāssid al-Sharīi 'ah al-Islāmiyyah, ed. El-Tahir el-Mesawi. Kuala Lumpur: alFajr.

29. Kuran, Timur. 1995. Islamic economics and the Islamic subeconomy. Journal of Economic Perspectives. 9 (4).

30. Mirakhor, Abbas. 1987. Muslim scholars and the history of economics: A need for consideration. American Journal of Islamic Social Sciences. 4(2): 245-276.

31. Haneef, Mohamed Aslam, and Hafas Furqani. 2009. Developing the ethical foundations of Islamic economics: Benefitting from Toshihiko Izutsu. Intellectual Discourse 17(2): 173-199.

32. Nayed, Aref Ali. 1992. The Unitary Qur'anic Hermenutics of Muhammad Baqir al-Sadr. Islamic Studies. 31(4): 443-449.

33. Nomani, Farhad, and Ali Rahnema. 1994. Islamic economic systems, Zed Books. California: University of California.

34. Ouda, Jasser. 2012. Maqāsid al-Sharī’a. Herndon USA: al-M'had al- ‘ālami lil fikr al-Islāmī.

35. Wilson, Rodney. 1998. The contribution o Muhammad Baqir al-Sadr to contemporary Islamic economic thought. Journal of Islamic Studies. 9(1): 46-59.

36. Abdul-Hasan, Sadeq, et al. 1996. Pregled islamske ekonomske misli. Sarajevo: El-Kalem.

37. Sahih International, Qur'an Online. Accessed 20 ${ }^{\text {th }}$ April 2015, http://quran.com/.

38. Virk, Tomo. 2003. Moderne literarne vede in njihove filozofsko teoretske osnove. Ljubljana: Univerza v Ljubljani, FF.

39. Wirth, Uwe. 2001. Abductive inference and literary theory-pragmatism, hermeneutics and semiotics. Accessed 25 April 2015, http://www.digitalpeirce.fee.unicamp.br/p-infwir.htm. 